\title{
Production and analysis of electrospun PA 6,6 and PVA nanofibrous surfaces for filtration
}

DOI: $10.35530 / I T .072 .05 .202026$

\section{ABSTRACT - REZUMAT}

\section{Production and analysis of electrospun PA 6,6 and PVA nanofibrous surfaces for filtration}

Electrospun nanofibrous surfaces were produced by using two different polymers (PA 6,6 and PVA) at three different levels of polymer feeding rate $(0.2,0.6$ and $1.0 \mathrm{ml} / \mathrm{h}$, respectively) and three different levels of production time in electrospinning $(5,10$ and 15 minutes, respectively) and the effect of polymer type, polymer feeding rate and production time was determined by analyzing unit weight and thickness of the nanofibrous membranes as well as fibre fineness and pore size distributions. The results showed that much finer fibres were produced by PA 6,6 polymer compare to $P V A$. The minimum average fibre fineness was $150.96 \mathrm{~nm}$ (by PA 6,6 polymer; $0.2 \mathrm{ml} / \mathrm{h} ; 5 \mathrm{~min}$.) while maximum fibre fineness was $243.43 \mathrm{~nm}$ (by PVA polymer; $0.6 \mathrm{ml} / \mathrm{h} ; 15 \mathrm{~min}$.). Similarly, the pore sizes of nanofibrous surfaces produced by PA 6,6 were smaller compare to the ones produced by PVA polymer. The results also indicated that coarser fibres were produced as the polymer feed rate and electrospinning time increased. In the second part of the work, composite structures were obtained by combining nanofibrous surfaces with PP non-woven material and their air permeability and filtration efficiency by using an aerosol having $0.2-0.33 \mathrm{~mm}$ diameter range were analyzed. The air permeability of PA 6,6 nanofibrous surfaces were much higher compare to the ones produced by PVA and quite high filtration efficiency $(99.901 \%)$ was obtained with PA 6,6 nanofibrous surfaces. Also, potential of these nanofibrous surfaces was evaluated by analysing chemical groups eliminated following their exposure to cigarette smoke which was chosen as a specific case study.

Keywords: electrospinning, nanofibre, PA 6,6, PVA, nanofibrous surface, filtration

\section{Producția și analiza suprafețelor nanofibroase electrofilate din PA 6,6 și PVA pentru filtrare}

Suprafețele nanofibroase electrofilate au fost produse prin utilizarea a doi polimeri diferiți (PA 6,6 și PVA) la trei niveluri diferite de viteză de alimentare a polimerului $(0,2,0,6$ și respectiv 1,0 ml/h), precum și trei intervale diferite de timp de producție în electrofilare (5, 10 și respectiv 15 minute), iar influența tipului de polimer, vitezei de alimentare a polimerului și timpului de producție a fost determinate prin analiza greutății unitare și a grosimii membranelor nanofibroase, precum și prin finețea fibrelor și distribuția mărimii porilor. Rezultatele au arătat că fibrele mult mai fine au fost produse din polimerul PA 6,6 comparativ cu PVA. Finețea medie minimă a fibrelor a fost de 150,96 nm (din polimerul PA 6,6; 0,2 $\mathrm{ml} / \mathrm{h} ; 5 \mathrm{~min}$.), în timp ce finețea maximă a fibrelor a fost de 243,43 nm (din polimerul PVA; 0,6 ml h; $15 \mathrm{~min}$.). În mod similar, dimensiunile porilor suprafețelor nanofibroase produse din PA 6,6 au fost mai mici în comparație cu cele produse din polimerul PVA. Rezultatele au indicat, de asemenea, că fibrele grosiere au fost produse pe măsură ce viteza de alimentare a polimerului și timpul de electrofilare au crescut. În cea de-a doua parte a lucrării, structurile compozite au fost obținute prin combinarea suprafețelor nanofibroase cu material nețesut PP, iar permeabilitatea acestora la aer și eficiența de filtrare au fost analizate prin utilizarea unui aerosol cu un interval al diametrului de 0,2-0,33 mm. Permeabilitatea la aer a suprafețelor nanofibroase de PA 6,6 a fost mult mai mare în comparație cu cele produse din PVA și s-a obținut o eficiență de filtrare destul de ridicată (99,901\%) cu suprafețe nanofibroase de PA 6,6. De asemenea, potențialul acestor suprafețe nanofibroase a fost evaluat prin analiza grupurilor chimice eliminate în urma expunerii lor la fumul de țigară, care a fost ales ca studiu de caz specific.

Cuvinte-cheie: electrofilare, nanofibră, PA 6,6, PVA, suprafață nanofibroasă, filtrare

\section{INTRODUCTION}

A filter media is utilised to purify air that contains solid particles (virus, mine dust etc.) or liquid particles (evaporated water, chemical solvents etc.), therefore filtration is mainly a seperation process. The main aim of such surfaces developed for filtration is to have pore sizes as minimum as possible while providing maximum filtration efficiency during use. As a result, including the finest possible fibres in a filtration media has been one of the important criteria for efficient removal of the particles. In conventional fibre production methods, however, the fibre fineness usually varies between 10-50 $\mu \mathrm{m}$ while it might be reduced down to 3-8 $\mu \mathrm{m}$ by meltblown technique [1]. However, not only the fibre fineness but also the pore size in a filter media matters as indicated above, i.e. mesh pore size must be small or thick mesh is required to remove ultrafine particles so that a filtration fan can blow the air with high pressure [2]. On the other hand, small particles such as between 0.04-0.4 $\mu \mathrm{m}$, are known as the most difficult to get caught during filtration. Therefore, developing a porous 
filtration mesh surface being able to catch particles of $0.3 \mu \mathrm{m}$ and below at high efficieny has been a challenging issue. As a result, development of filtration surfaces including very fine fibres and also being able to catch such a small particles is a need for better filtration. In this respect, electrospun nanofibre membranes, which can replace glass fibres and charcoal filters as functional nanofibre based filters or functional nanofibre combinations [3], gained an important potential and have been used in air filtration during last 20 years while a filtration market up to 700 billion USDollar in 2020 was estimated indicating the potential in this field $[4,5]$. In this respect, there is also a continuous search for new production perspectives for electrospun nanofibres in filtration. Production of nonwovens from short electrospun poymer nanofibre dispersion [6]; production of ultrafine (33 and $120 \mathrm{~nm}$ ) polyamide 6 nanofibre membranes formed with needleless electrospinning [7] or fabrication of flexible and strong carbon nanofibre (CNF) membranes by electrospinning capable of efficiently rejecting NP of different sizes and materials such as $\mathrm{Au}, \mathrm{Ag}$, and $\mathrm{TiO}_{2}$ from aqueous solution [8] can be given as examples.

Mainly PAN based nanofibre membranes produced by electrospinning is developed for ultrafiltration and nanofiltration $[9,10]$ while potential of other polymers have also been explored. Tsai et al. analyzed filtration performance of electrospun Polycarbonate, PU ve PEO nanofibre surfaces having $100-500 \mathrm{~nm}$ fibre fineness and tested for $300 \mathrm{~nm} \mathrm{NaCl}$ aerosols by comparing with conventional meltblown fabrics [11]. They reported filtration efficiency $(78 \%)$ of $3 \mathrm{~g} / \mathrm{m}^{2}$ electrospun PEO is equivalent to that of $100 \mathrm{~g} / \mathrm{m}^{2}$ of uncharged meltblown fabrics. Similarly, Ahn et al. studied the performance of electrospun PA6 nanofibre surfaces at different unit weights including fibres of $80-200 \mathrm{~nm}$ and reported surfaces of $5.75 \mathrm{~g} / \mathrm{m}^{2}$ and $10.75 \mathrm{~g} / \mathrm{m}^{2}$ exhibit HEPA level filtration efficiency [12]. Qin and Wang reported high filtration efficiency of electrospun PVA nanofibre surfaces with average fibre diameter of $200 \mathrm{~nm}$ and average porosity of 740 $\mathrm{nm}$ when tested with $\mathrm{NaCl}$ areosols of $0.6 \mu \mathrm{m}$ [13]. On the other hand, Guibo et al., reported high filtration efficiency of electrospun PA6 surfaces, which have average fibre fineness of $177 \pm 39 \mathrm{~nm}$ and porosity of $147.4 \pm 42.9 \mathrm{~nm}$, reaching up to $99,98 \%$ efficiency levels produced at different electrospinning production times [4]. Li and Gao compared filtration efficiency of electrospun PVA nanofibre membranes produced at different concentrations and electrospinning production times [14]. The average fibre fineness was $92 \pm 21 \mathrm{~nm}$ while they used $75 \pm 20 \mathrm{~nm}$ $\mathrm{NaCl}$ particles at $32 \mathrm{It} / \mathrm{min}$ airflow reporting $99.95 \%$ efficiency. Similarly, Hung reported higher filtration performance of PEO nanofibre surfaces with fibre fineness of $100-400 \mathrm{~nm}$ for aerosols of $50-500 \mathrm{~nm}$ compared to the microfibre surfaces [15]. Regarding PEO nanofibrous membranes, the effect of nanofibre packing density and nanofibre layer thickness on filtration performance was studied as well by electrospinning these fibres on a microfibre substrate having mean PEO fibre diameter of $208 \mathrm{~nm}$ [16]. The results showed that the most penetrating particle sizes (MPPS) decreased with nanofibre packing density as the MPPS ( $\mathrm{NaCl}$ aerosol size ranging from 50 to $480 \mathrm{~nm}$ ) decreased from 140 to $90 \mathrm{~nm}$ when nanofibre packing density was increased from 3.9 to $36 \times 10^{-3}$ while the effect of nanofibre layer thickness on MPPS is less prominent than that of nanofibre packing density.

On the other hand, Heikkila et al. studied filtration performance of different type of polyamides (PA 6, PA 6,6; PA 6,12; PA 6,14; PA 10,12 and PA 10,14) reporting that the finest fibres $(120 \pm 30 \mathrm{~nm})$ can be obtained by PA 6,6 polymer [17] while effect of electrospinning parameters (such as polymer solution concentration, voltage, tip-collector distance) on filtration performance of PA nanofibrous surfaces electrospun during 15, 30, 45 and 60 min was reported by Aliabadi [18]. There was a significant increase in filtration efficiency of surfaces electrospun at $30 \mathrm{~min}$. compare to the ones produced at $15 \mathrm{~min}$. while the difference was not significant between the surfaces produced at $30 \mathrm{~min}$. and $45 \mathrm{~min}$. The effect of electrospinning parameters such as polymer solution concentration, voltage, tip-collector distance and duration of electrospinning $(18,20,22$ and 24 min.) on filtration performance was also studied by Wei et al. by developing so-called "needleless double rings slit electrospinning" system producing PAN nanofibrous surfaces [19]. The results showed that mean pore diameter and its distribution increased as spinning time increase and filtration efficiency was above $99.9 \%$ for surfaces produced at $18 \mathrm{~min}$. while filtration resistance increased dramatically when spinning time increased from 18 to $24 \mathrm{~min}$. Similarly, Ahne et al. studied the effect of electrospinning parameters such as polymer solution concentration, voltage, tip-collector distance and duration of electrospinning (up to 30 min.) on filtration performance as well but producing cellulose acetate (CA) based nanofibres obtaining maximum filtration efficiency of $99.8 \%$ for samples obtained with deposition time of $30 \mathrm{~min}$. while maximum filter quality factor was $0.05 \mathrm{~Pa}^{-1}$ for a filter corresponding to a CA concentration of $20 \mathrm{wt}$ \% , a tip-tocollector distance of $12.5 \mathrm{~cm}$, a voltage of $8 \mathrm{kV}$ and a deposition time of 5 minutes [20]. The effect of electrospinning time on filtration performance of PAN nanofibrous surfaces was also studied showing that PAN deposition time during electrospinning affected the filter quality [21]. The results showed that shorter deposition time of PAN nanofibre mats yields a better quality factor. It was also observed that thickness uniformity of nanofibre mats was getting worse as the deposition time increased and therefore diminished filter quality. In another study, nylon nanofibre filters 
were fabricated with five different solution concentrations and five different electrospinning times $(1,1.5,2$, 3 , and $4 \mathrm{~h}$ ) to investigate the effect of fibre diameter, filter thickness, packing density and face velocity while a semi-empirical model was applied to predict $\mathrm{PM}_{2.5}$ removal efficiency [22]. An air filter based on PVDF branched nanofibres having a basis weight of $1 \mathrm{~g} / \mathrm{m}^{2}$ with outstanding filtration efficiency (99.999\%) to $0.26 \mu \mathrm{m}$ sodium chloride particles under pressure drop of $126.17 \mathrm{~Pa}$ can be given as another interesting work in this field [23]. On the other hand, Daneleviciute-Vaisniene et al. produced electrospun PVA nanofibre membranes, but different from above works they analysed cigarette smoke filtration performance indicating that PVA surfaces were able to catch organic polar grups, ethers and carboxyl groups [24]. In this study, FT-IR analysis results of two layers (PP+PVA web) was compared with PP non-woven fabric layer itself after exposure to cigarette smoke filtration which would in fact need further confirmation including comparison of two identical structures.

Use of nanofibre webs also contributes significantly to remove small liquid drops in submicron range as well. Hajra et al. reported that small addition of nanofibres on the substrate of glass fibres effectively captures oil droplets of $210 \mathrm{~nm}$ diameter [25]. There are commercial two-layer composite nanofibre webs with supporting micron-fibre layer as dust filter bags capturing particles below $500 \mathrm{~nm}$ diameter size [26]. A pleated filter media prepared by nanofibres of 250 $\mathrm{nm}$ size wetlaid on a cellulose substrate of $10 \mathrm{~mm}$ fibre diameter is another example [27] while their potential for textile effluent treatment has also been studied [28]. A recent work by Shao et al. also show potential of composite nanofibrous membranes produced by electrospinning of polyvinyl chloride (PVC) nanofibres and polyamide-6 (PA6) nanofibres [29]. The removal efficiency was $98.75 \%$ for sodium chloride $(\mathrm{NaCl})$ aerosol particles with a diameter of 0.3 $\mu \mathrm{m}$ as their performance was attributed to triboelectric effect between these two adjacent nanofibre membranes.

As cigarette smoke was chosen as a case study in this work, a brief discussion of some main findings in this field has also been included. Poisonuous chemicals in cigarette smoke is known as one of the main reasons for cancer and it is combination of over 4700 chemical compounds [30] including nicotin as well as poisonuous compounds like polycyclic aromatic hydrocarbons (PAHs) and N-nytrocamins [31]. IARC, on the other hand, indicates that 9 out of 50 chemicals in cigarette smoke are in Group 2A carcinogen category [32]. Therefore, an efficient filtration of cigarette smoke is a real need and a challenging issue. Today, generally natural/synthetic fibrous materials in tow form are used in cigarette filtres, by enhancing their filtration ability by additives or special chemical compounds that have been generally kept as a trade secret. The fibres used for cigarette filtres are mainly cellulose diacetate or PP, however, even use of silk fibres has been reported [33]. By adding Glycine to remove aldehites from cigarette smoke, or use of 3-aminopropylsyl groups binded by silica gel [34] or CGC substance obtained from Ginkgo biloba plant [35], or use of activated carbon within fibre tows [36] are examples for different approaches. It is also clear that maximising specific surface of fibres is advantageous for an efficient filtration, therefore fibres with specific cross-section, such as Y-crosssection, have also been used [37].

In the light of above works, electrospun nanofibre membranes were produced and their properties were analysed. During production of nanofibrous surfaces, two different polymers (PA 6,6 and PVA) were used. PA 6,6 was specificly chosen due to its high potential for finer fibre production while PVA was chosen mainly because of its common use in electrospinning for easy spinning conditions. Nanofibrous surfaces at different unit weights and thicknesses were electrospun at three different levels of polymer injection speed $(0.2,0.6$ and $1.0 \mathrm{ml} / \mathrm{h}$, respectively) and three different electrospinning times (5, 10 and 15 min., respectively).

\section{MATERIAL AND METHOD}

\section{Production of nanofibre surfaces}

Single needle electrospinning set up, that includes Matsusada AU30-DC (max. 30 kV) high-power supply and Newera Ne-300 polymer injection pump, was used for production of nanofibrous surfaces [38]. The conductivity of polymers was measured by Eutech conductivity tester while Brookfield DV-F viscosimeter was used for viscosity. During production, polymer fibres were collected as membrane form onto a PP non-woven surface. Main production parameters were summarised in table 1 and table 2 , respectively.

\begin{tabular}{|c|c|c|c|c|c|}
\hline \multicolumn{7}{|c|}{ ELECTROSPINNING PARAMETERS } \\
\hline Polymer & $\begin{array}{c}\text { Polymer } \\
\text { concentration } \\
\text { wt (\%) }\end{array}$ & Solvent & $\begin{array}{c}\text { Needle gauge } \\
(\mathbf{m m})\end{array}$ & $\begin{array}{c}\text { Distance between } \\
\text { needle and collector } \\
(\mathbf{c m})\end{array}$ & Voltage (kV) \\
\hline PVA & 10 & Distilled water & 0.7 & 10 & 20 \\
\hline PA 6,6 & 10 & Formic acid & 0.7 & 20 \\
\hline
\end{tabular}




\begin{tabular}{|c|c|c|c|}
\hline \multicolumn{4}{|c|}{$\begin{array}{c}\text { ELECTROSPUN NANOFIBROUS SURFACES } \\
\text { PRODUCED IN THE WORK }\end{array}$} \\
\hline Polymer & $\begin{array}{l}\text { Sample } \\
\text { code }\end{array}$ & $\begin{array}{l}\text { Production time } \\
\text { in electrospin- } \\
\text { ning (min.) }\end{array}$ & $\begin{array}{c}\text { Polymer } \\
\text { feed rate } \\
(\mathrm{ml} / \mathrm{h})\end{array}$ \\
\hline \multirow{9}{*}{ PVA } & PVA 5.02 & \multirow{3}{*}{5} & 0.2 \\
\hline & PVA 5.06 & & 0.6 \\
\hline & PVA 5.1 & & 1.0 \\
\hline & PVA 10.02 & \multirow{3}{*}{10} & 0.2 \\
\hline & PVA 10.06 & & 0.6 \\
\hline & PVA 10.1 & & 1.0 \\
\hline & PVA 15.02 & \multirow{3}{*}{15} & 0.2 \\
\hline & PVA 15.06 & & 0.6 \\
\hline & PVA 15.1 & & 1.0 \\
\hline \multirow{9}{*}{ PA 6,6} & PA 5.02 & \multirow{3}{*}{5} & 0.2 \\
\hline & PA 5.06 & & 0.6 \\
\hline & PA 5.1 & & 1.0 \\
\hline & PA 10.02 & \multirow{3}{*}{10} & 0.2 \\
\hline & PA 10.06 & & 0.6 \\
\hline & PA 10.1 & & 1.0 \\
\hline & PA 15.02 & \multirow{3}{*}{15} & 0.2 \\
\hline & PA 15.06 & & 0.6 \\
\hline & PA 15.1 & & 1.0 \\
\hline
\end{tabular}

\section{Analysis of nanofibrous surfaces and their filtration performance}

Following production of nanofibre membranes, average unit weights of surfaces were determined by testing 5 samples each. A digital micrometer (Kanon, EMS-150 model) with $0.01 \mathrm{~mm}$ accuracy was used for thickness measurement of the surfaces. SEM (Quanta, Feg 250) was used to analyse the fibre fineness and fineness variation within the nanofibre membranes together with Adobe Photoshop CS6. Additionally, pore sizes of nanofibre membranes were analyzed by Quanta Chrome tester according to ASTM F316-03 (2011). Following these main characterisation analyses, air permeability of the membranes were tested by Proser air permeability tester according to TS 391 EN ISO 9237:1999 at sample size of $5 \mathrm{~cm}^{2}$ and pressure of $100 \mathrm{kPa}$. Certitest 8130 automatic filtration tester having liquid aerosol diameter range of $0.2-0.33 \mathrm{~mm}$ and $90-95 \mathrm{lt} / \mathrm{min}$ flow rate was used following EN 149:2001 to analyse filtration efficiency of the nanofibrous surfaces. Also, a basic test set up was used to simulate a simple cigarette smoke filtration (figure 1) as a specific case. In this set up, cigarette smoke was applied for each sample for $1 \mathrm{~min}$. and following this, nanofibre surfaces are analyzed by FT-IR (Thermo iS10) to detect the chemical groups filtrated.

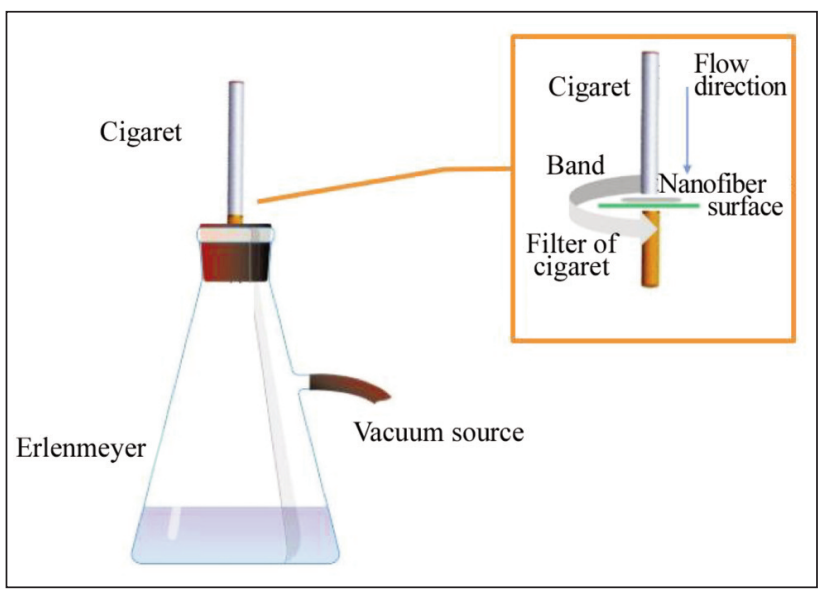

Fig. 1. The simple set-up used for cigarette smoke filtration

\section{RESULTS AND DISCUSSIONS}

\section{Viscosity and conductivity of polymer solvents}

The typical viscosity and conductivity results of the polymer solvents at $25^{\circ} \mathrm{C}$ were given below. The results showed that viscosity of both polymers was similar to each other while the conductivity of PA 6,6 polymer was higher (table 3 ).

\begin{tabular}{|c|c|c|}
\hline \multicolumn{3}{|c|}{$\begin{array}{r}\text { TISCOSle } 3 \\
\hline \multicolumn{3}{|c|}{\text { OF POLYMER SOLVENTS }}\end{array}$} \\
\hline $\begin{array}{c}\text { Polymer } \\
\text { solutions }\end{array}$ & $\begin{array}{c}\text { Viscosity } \\
\text { (cP) }\end{array}$ & $\begin{array}{c}\text { Conductivity } \\
\text { (mS/cm) }\end{array}$ \\
\hline PVA & 810.0 & 575 \\
\hline PA 6,6 & 800.8 & 658 \\
\hline
\end{tabular}

\section{Characterisation of nanofibrous surfaces}

The typical SEM images show that fibrous membranes were evenly produced by these two polymers (table 4). As the polymer feed rate increased during electrospinning, coarser fibres were produced as expected since the effect of polymer feed rate on fibre fineness is well-known as lower flow rates yielding fibres with smaller diameters [39, 40], although the increase in fibre fineness is more significant when PVA polymer was used (figure 2,a). The variation in fibre fineness also increased at higher polymer feeding rate. The effect of electrospinning time on fibre fineness was also analyzed as the results indicate that fibres get coarser as production time in electrospinning increases (figure $2, b$ ). This is probably as a result of the decrease in conductivity when fibrous membrane surfaces get thicker on the collector during production in electrospinning.

Regarding the effect of electrospinning time on unit weight and thickness of fibrous mesh, the results were given by figure 3 . These findings show that both unit weight and thickness values increase as the electrospinning time increases, as expected.

However, there is almost $95 \%$ increase in unit weight at $10 \mathrm{~min}$. compare to $5 \mathrm{~min}$. electrospinning time, 


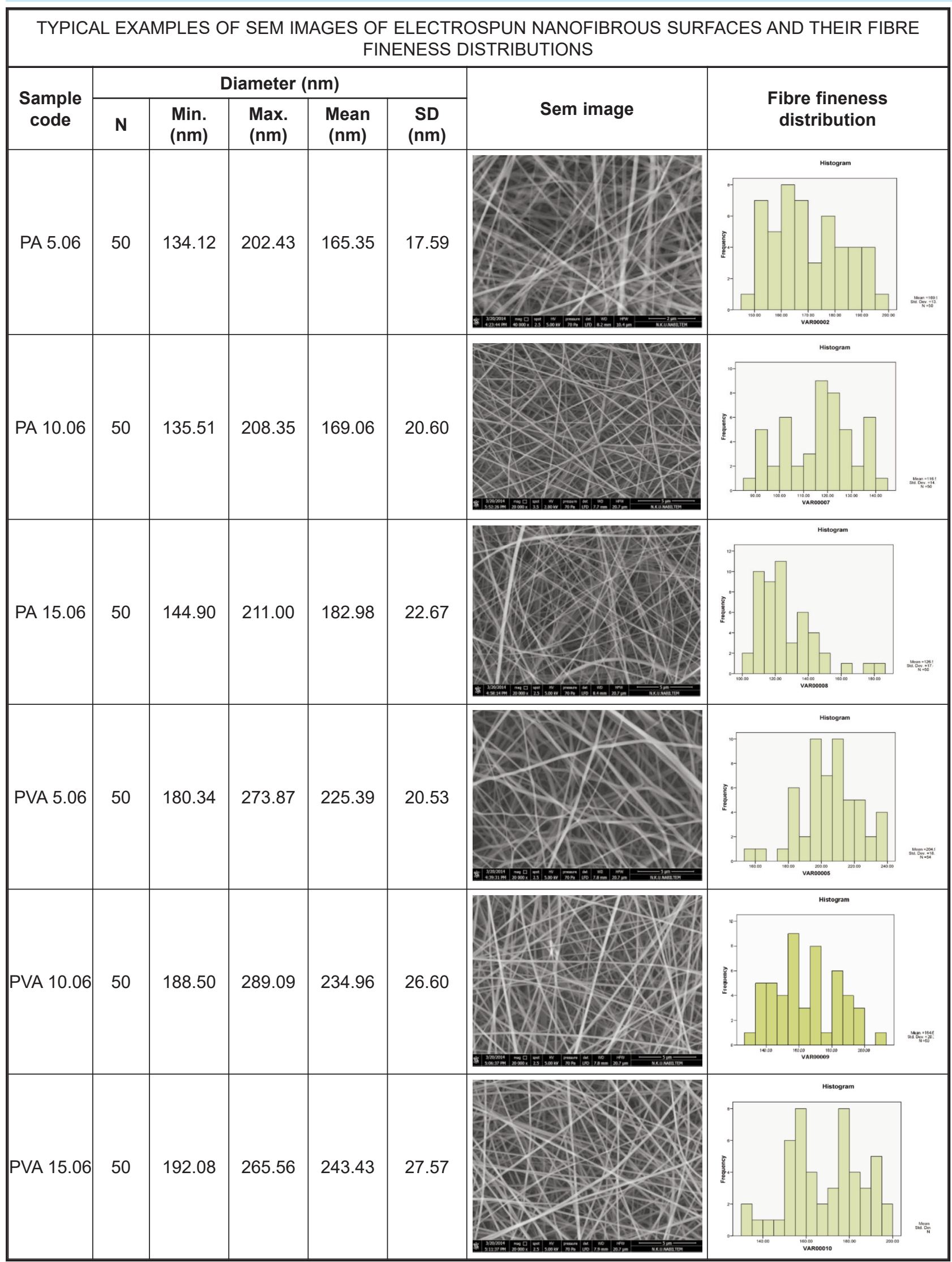

while the increase at $15 \mathrm{~min}$. is much lower. This result can be attributed to the decrease in conductivity on collector surface due to the increase in fibre layer thickness as production continues. Similar findings were reported by Guibo et al. earlier during electrospinning of PA 6 polymer [4]. However, with PVA polymer, the increase in unit weight at $10 \mathrm{~min}$. compare to $5 \mathrm{~min}$. is $\% 71$, i.e. much lower value compare to the results obtained by PA 6,6 polymer. That can be explained by lower conductivity of this polymer. The typical porosity values of the nanofibrous surfaces produced by this work were also analysed by 


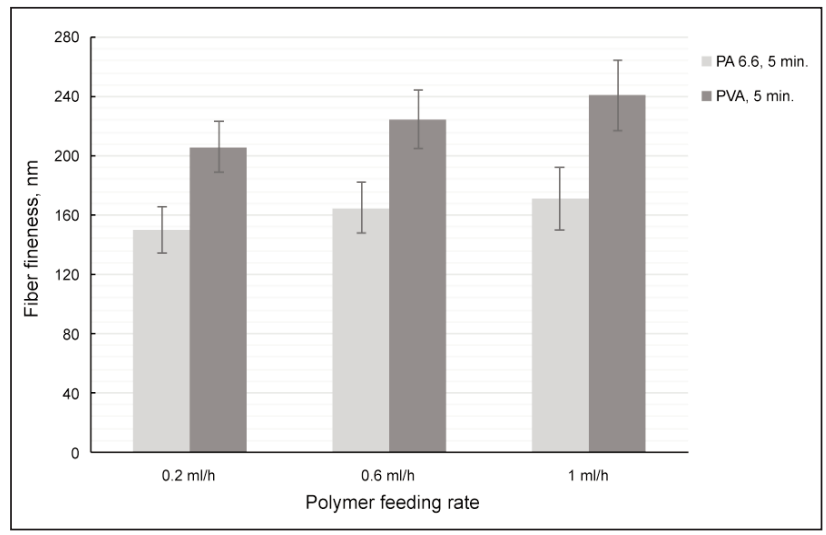

a

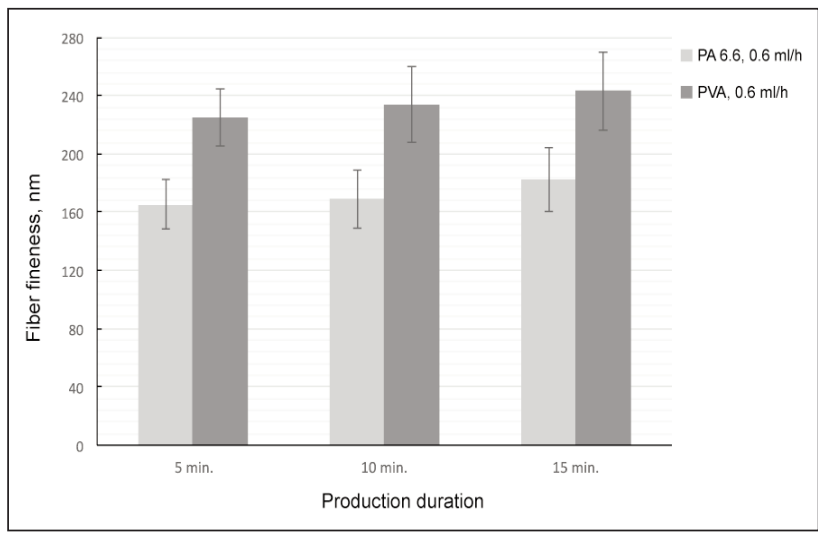

$\boldsymbol{b}$

Fig. 2. The effect of: $a$ - polymer feeding rate on fibre fineness; $b$ - production time in electrospinning on fibre fineness

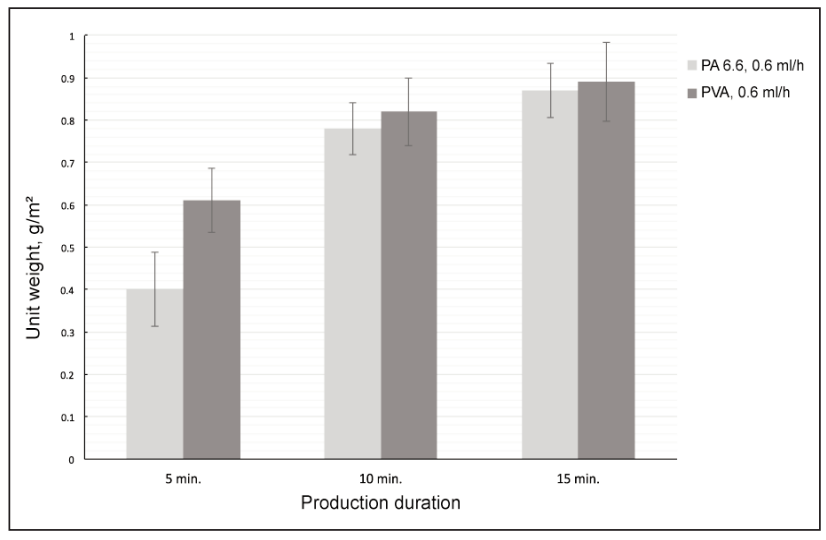

a

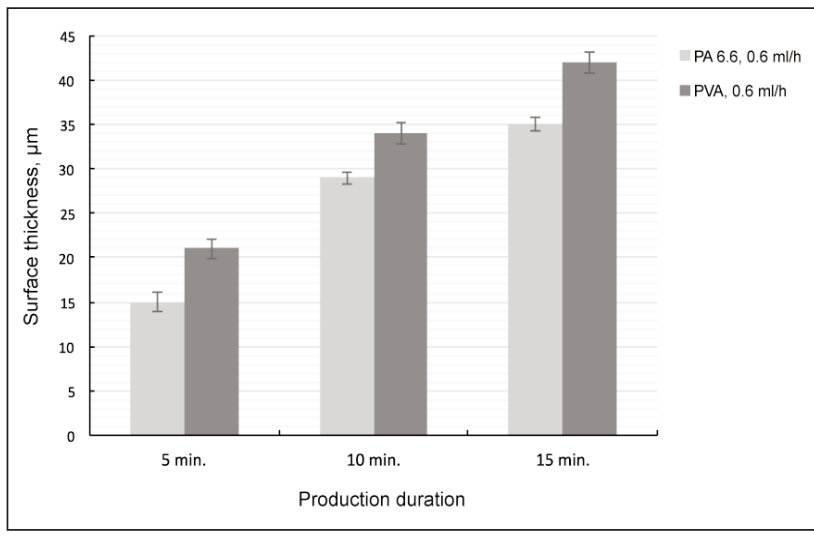

b

Fig. 3. The effect of production time in electrospinning on unit weight (a) and thickness $(b)$ of nanofibrous surfaces

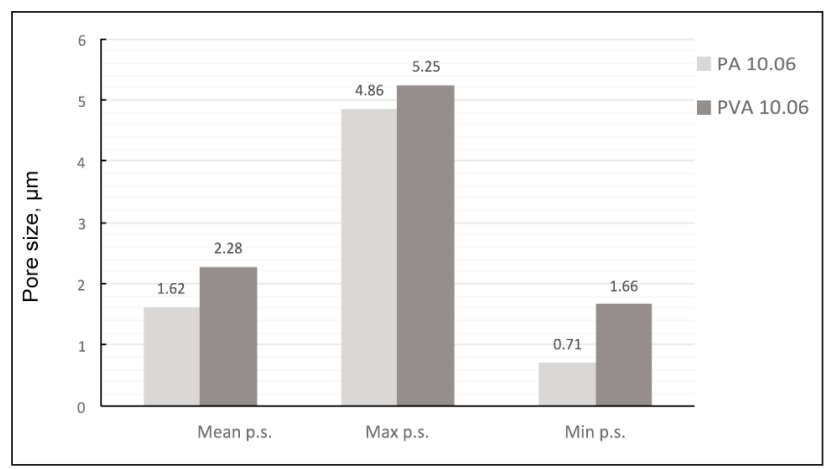

Fig. 4. Typical pore size distrubutions of electrospun nanofibrous surfaces

testing one sample type only to obtain a general idea (figure 4). The results show that nanofibrous surfaces produced by PA 6,6 have smaller pore size compare to PVA indicating their potential for better filtration performance. Smaller pore sizes with PA 6,6 nanofibrous surfaces is an expected result as surfaces with larger fibres would have larger holes [41].

\section{Filtration performance}

The air permeability test results of PA 6,6 and PVA nanofibrous surfaces were given by figure 5 . The test results showed that fibrous meshes with PA 6,6 polymer exhibit better air permeability performance, most probably owing to much finer fibres that these filter media contain. On the other hand, the results showed that air permability of structures decreased as electrospining time and polymer feed rate increased due to the increase in both thickness of mesh layer and its constituent fibres. Similarly, significant effect of spinning time on the filtration property of the nanofibre membrane, especially on filtration resistance was reported earlier [19]. However, it is worth noting that effect of production time was more significant when PVA polymer was used compare to PA 6,6.

Following air permability tests, the structures were also tested for liquid aerosol filtration efficiency. These tests were applied for PA 6,6 nanofibrous surfaces only as the filtration efficiency tests were failed during the test of PVA meshes probably due to their low tenacity and sensitivity for aerosols as well as their low air permeability as indicated by figure 5 . Regarding PA 6,6 nanofibrous surfaces, the test results given by figure 6 indicate an increase in filtration efficiency as electrospinning time and feeding rate increases, as expected. It was reported earlier that longer fibre production time makes the fibrous media denser and has positive effect on filtration efficiency [42] also indicating an increase in filtration 


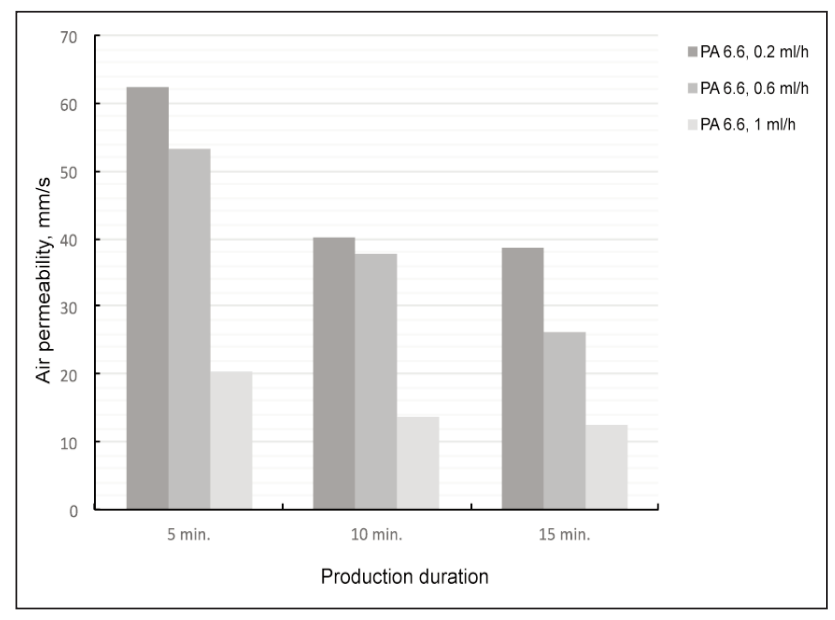

a

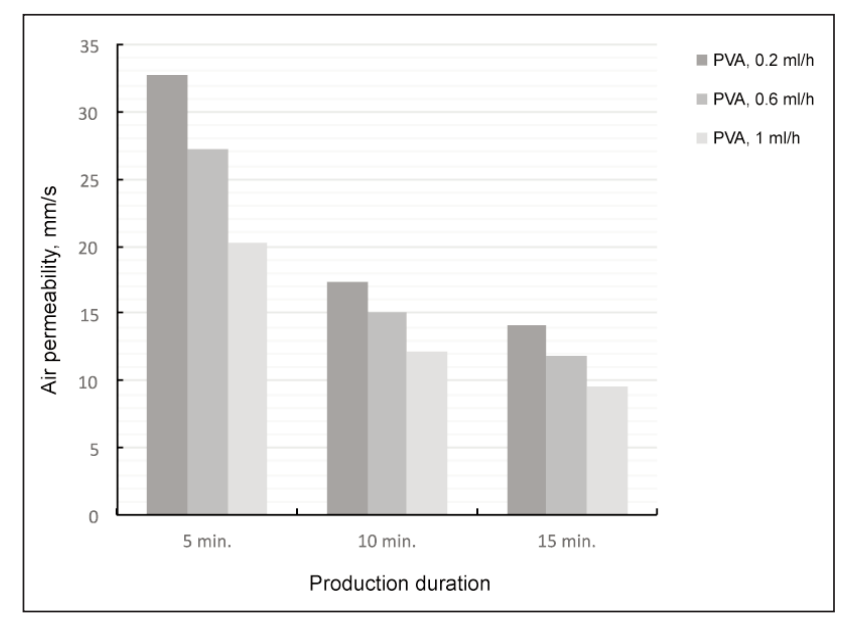

b

Fig. 5. Air permeability test results of nanofibrous surfaces produced by: $a-P A 6,6 ; b-P V A$

efficiency by increase in spinning time [19]. The highest performance was obtained with the structures produced at $1.0 \mathrm{ml} / \mathrm{h}$ polymer feed rate and at $10 \mathrm{~min}$. electrospinning time. However, the increase in efficiency of the structures produced at $5 \mathrm{~min}$. and $10 \mathrm{~min}$. was greater compare to the ones produced at $10 \mathrm{~min}$. and $15 \mathrm{~min}$.

Finally, the nanofibrous membranes were exposed to cigarette smoke by using filtration set up shown by figure 1. Then, FT-IR spectrums of nanofibrous structures produced by PA 6,6 and PVA polymers, given by figure 7 was analyzed in comparison with unexposed structures. Following filtration, regarding PA 6,6 membranes; the peak at $1713 \mathrm{~cm}^{-1}$ belong to $(\mathrm{C}=\mathrm{O})$ bonds indicating filtration of aldehit, kethon, carboxylic acids or esther functional groups while the peak at $1053 \mathrm{~cm}^{-1}$ indicates (C-O) bonds at primer alcohols, ethers or esters. For PVA nanofibrous membranes, however, peaks at $2917 \mathrm{~cm}^{-1}, 1707 \mathrm{~cm}^{-1}$ and $1600 \mathrm{~cm}^{-1}$ belonging to alkans, carbonyl groups and aromatic rings, respectively were oserved indicating aldehits, esthers, carboxyclic acides and kethons. As indicated earlier, cigarette smoke filtra-

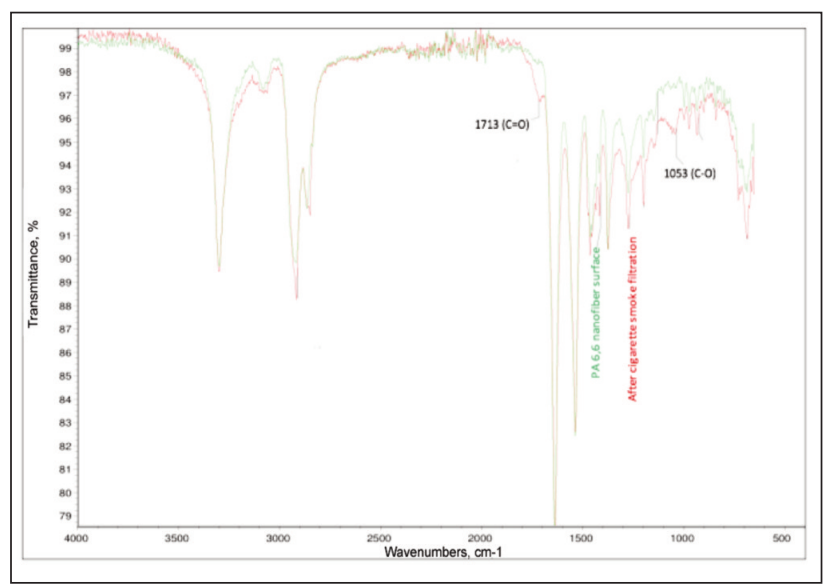

a

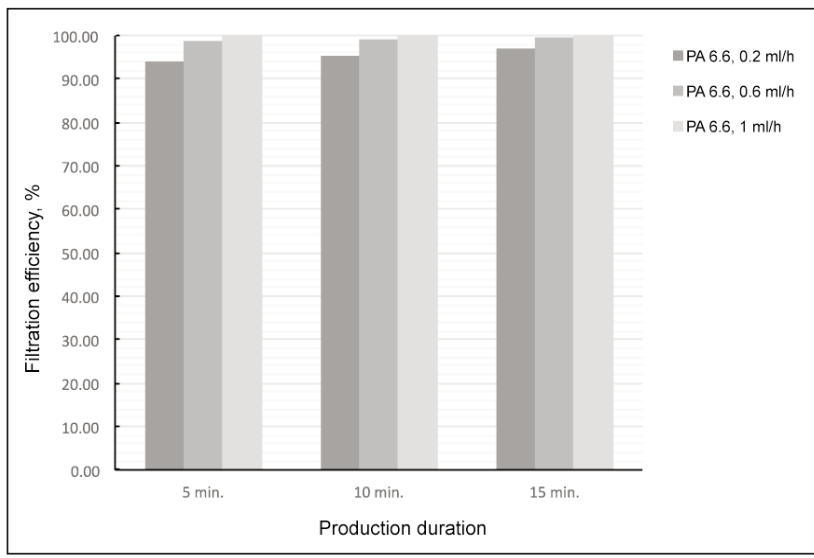

Fig. 6. Aerosol filtration efficiency of nanofibrous surfaces produced by PA 6,6

tion performance of electrospun PVA nanofibre membranes was studied earlier as well indicating that PVA surfaces were able to catch organic polar grups, ethers and carboxyl groups [24], however FT-IR analysis results of two layers (PP+PVA web) was compared with only PP non-woven fabric layer itself after

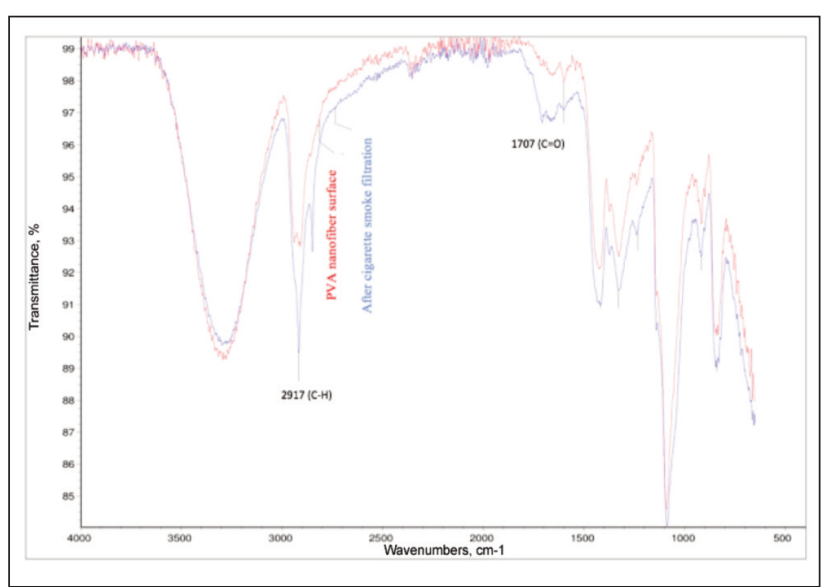

b

Fig. 7. FT-IR spectrum of: $a$ - PA 6,6 nanofibrous structures; $b$ - PVA nanofibrous structures before and after cigarette smoke filtration 
exposure to cigarette smoke filtration. Therefore the results at figure 7 can be considered a further study by comparing results of two identical nanofibrous structures before and after smoke filtration.

\section{CONCLUSIONS}

In this work, 18 different nanofibrous surfaces were produced by PVA and PA 6,6 polymers by electrospinning at three different levels of polymer feeding rate $(0.2 ; 0.6$ and $1.0 \mathrm{ml} / \mathrm{h}$, respectively) and three different levels of electrospinning time $(5,10$ and 15 min., respectively). These structures were analysed in terms of fibre fineness distrubition, membrane thickness and unit weight. Then, selected nanofibrous surfaces were analysed for their pore size distributions, air-permeability, aerosol filtration efficiency. In addition to that, they were tested on a simple set-up to analyse their cigarette smoke filtration potential that was chosen as a specific case.

The results show that much finer fibres were produced by PA 6,6 polymer compare to PVA polymer. The pore sizes of PA 6,6 membranes were smaller in comparison to PVA membranes as well. During electrospinning process, much coarser fibres were produced as the polymer feed rate and electrospinning time increased reducing air-permeability of these nanofibrous surfaces as expected. The minimum average fibre fineness was $150.96 \mathrm{~nm}$ produced by using PA 6,6 polymer at $0.2 \mathrm{ml} / \mathrm{h}$ polymer feed rate and $5 \mathrm{~min}$. production time while maximum average fibre fineness was $243.43 \mathrm{~nm}$ produced by using PVA polymer at $0.6 \mathrm{ml} / \mathrm{h}$ and $15 \mathrm{~min}$. The air permeability of PA 6,6 nanofibrous surfaces were much higher compare to the ones produced by PVA. Aerosol filtration efficiency test results showed quite high efficiency $(99.901 \%)$ can be obtained with PA 6,6 nanofibrous surfaces (electrospun at $1 \mathrm{ml} / \mathrm{h}$ and $10 \mathrm{~min}$.) indicating that PA 6,6 nanofibrous surfaces have potential for such applications. The test results also showed that filtration efficiency increased as polymer feed rate and electrospinning time increased. On the other hand, the cigarette smoke tests carried out in this work showed that mainly PA 6,6 membranes can filtrate carboxylic acids and primer alcohols while PVA membranes can filtrate alkans.

\section{ACKNOWLEDGEMENT}

The authors would like to thank Tekirdağ Namık Kemal University, Scientific Research Project Unit as this work was supported by project number NKUBAP.00.17.YL.13.05. The authors also would like to thank $3 \mathrm{M}$ San. Tic. A. Ş. and Denge Kimya ve Tekstil San. Tic. A.Ş. (Tekirdağ, Turkey) for providing their facilities during some part of the tests.

\section{REFERENCES}

[1] Nataraj, S.K., Yang, K.S., Aminabhavi, T.M., Polyacrylonitrile-Based Nanofibres a State of the Art Review, In: Progress in Polymer Science, 2012, 37, 487-513

[2] Ramakrishna, S., Fujihara, K., An Introduction to Electrospinning and Nanofibres, World Scientific Publishing, USA, 2005

[3] Sundarrajan, S., Tan, K.L., Lim, S.H., Ramakrishna, S., Electrospun Nanofibres for Air Filtration Applications, In: Procedia Engineering, 2014, 75, 159-163

[4] Guibo, Y., Qing, Z., Yahong, Z., Yin, Y., Yumin, Y., The Electrospun Polyamide 6 Nanofibre Membranes Used As High Efficiency Filter Materials, In: J. of Applied Polymer Science, 2013, 128, 1061-1069

[5] Ustün, A., Nanofibre Production for Air Filtration, MSc Thesis, Denizli Pamukkale University, Natural\&Applied Science Institution, Turkey, 2011

[6] Langner, M., Greiner, A., Wet-Laid Meets Electrospinning: Nonwovens for Filtration Applications from Short Electrospun Polymer Nanofibre Dispersions, In: Macromol. Rapid Commun, 2016, 37, 351-355

[7] Yan, S., Yu, Y., Ma, R., Fang, J., The Formation of Ultrafine Polyamide 6 Nanofibre Membranes with Needleless Electrospinning for Air Filtration, In: Polym. Adv. Technol., 2019, 30, 1635-1643

[8] Faccini, M., Borja, G., Boerrigter, M., Martín, D., Crespiera, S. M., Vázquez-Campos, S., Aubouy, L., Amantia, D., Electrospun Carbon Nanofibre Membranes for Filtration of Nanoparticles from Water, In: J. of Nanomaterials, 2015, Article ID 247471, https://doi.org/10.1155/2015/247471

[9] Yoon, K., Kim, K., Wang, X., Fang, D., High Flux Ultrafiltration Membranes Based on Electrospun Nanofibrous PAN Scaffolds and Chitosan Coating, In: Polymer, 2006, 47, 2434-2441

[10] Menkhaus, T.J., Varadaraju, H., Zhang, L., Schneiderman S., Electrospun Nanofibre Membranes Surface Functionalized with 3-Dimensional Nanolayers As An Innovative Adsorption Medium with Ultra-High Capacity and Throughput, In: Chem. Commun., 2010, 46, 3720-3722

[11] Tsai, P.P., Schreuder-Gibson, H., Gibson, P., Different Electrostatic Methods for Making Electrect Filters, In: Journal of Electrostatics, 2002, 54, 333-341

[12] Ahn, Y.C., Park, S.K., Kim, G.T., Hwang, Y.J., Lee, C.G., Shin, H.S., Lee, J.K., Development of High Efficiency Nanofilters Made of Nanofibres, In: Current Applied Physics, 2006, 6, 6, 1030-1035

[13] Qin, X., Wang, S., Filtration Properties of Electrospinning Nanofibres, In: Journal of Applied Polymer Science, 2006,102, 1285-1290

[14] Li, J., Gao, F., Needleless Electrospun Nanofibres Used For Filtration of Small Particles, In: Express Polymer Letters, 2013, 7, 8, 683-689

[15] Hung, C., Experimental Investigation and Theoretical Analysis on Air Filtration of Sub-micron Aerosols by Nanofibre Filter, PhD Thesis, Hong Kong Polytechnic University, Hong-Kong, 2010

[16] Leung, W.W., Hung, C., Yuen, P., Effect Of Face Velocity, Nanofibre Packing Density And Thickness On Filtration Performance Of Filters With Nanofibres Coated On A Substrate, In: Seperation and Purification Technology, 2010, $71,30-37$ 
[17] Heikkila, P., Taipale, A., Lehtimaki, M., Harlin, A., Electrospinning of Polyamides with Different Chain Compositions for Filtration Application, In: Polymer Engineering and Science, 2008, 48, 1168-1176

[18] Aliabadi, M., Effect of Electrospinning Parameters on the Air Filtration Performance Using Electrospun Polyamide6 Nanofibres, In: Chem. Ind. Chem. Eng. Q., 2017, 23, 4, 441-446

[19] Wei, L., Zhang, H., Qin, X., Fabricated Narrow Diameter Distribution Nanofibre For An Air Filtration Membrane Using A Double Rings Slit Spinneret, In: Textile Research Journal, 2019, 89, 6, 936-947

[20] Ahne, J., Li, Q., Croiset, E., Tan, Z., Electrospun Cellulose Acetate Nanofibres For Airborne Nanoparticle Filtration, In: Textile Research Journal, 2019, 89, 15, 3137-3149

[21] Zhang, Q., Welch, J., Park, H., Wu C., Sigmund, W., Marijnissen, J.C.M., Improvement In Nanofibre Filtration By Multiple Thin Layers Of Nanofibre Mats, In: J. of Aerosol Science, 2010, 41, 230-236

[22] Bian, Y., Wang, S., Zhang, L., Chen, C., Influence Of Fibre Diameter, Filter Thickness, And Packing Density On PM2.5 Removal Efficiency Of Electrospun Nanofibre Air Filters For Indoor Applications, In: Building and Environment, 2020, 170, 106628

[23] Zaarour, B., Tina, H., Zhu, L., Jin, X., Branched Nanofibres With Tiny Diameters For Air Filtration Via One-Step Electrospinning, In: J. of Industrial Textiles, 2020, 1-13

[24] Daneleviciute-Vaisniene, A., Katunkis, J., Buika, G., Electrospun PVA Fibres for Gas Filtration Applications, In: J. of Fibres\&Textiles in Eastern Europe, 2009, 17, 40-43

[25] Hajra, M.G., Mehta, K., Chase, G.G., Effects of Humidity, Temperature and Nanofibres on Drop Coalescence in Glass Fibre Media, In: Serp. Purif. Technol., 2003, 20, 79-98

[26] Emig, D., Klimmek, A., Raabe, E., Dust filter bag containing nano non-woven tissue, US Patent 6,395,046 B1, 2002

[27] Grafe, T.H., Graham, K.M., Polymeric Nanofibres and Nanofibre Webs: A New Class of Nonwovens, International Non-wovens Technical Conference, Atlanta-USA, 2002

[28] Khanmohamadi, S., Gharehaghaji, A.A., Hoseini, S.A., Study on the Performance of Nanofibrous Filters For Colored Effluent Treatment, International Innovative Textile Congress (Icontex2011), İstanbul-Turkey, 20-22 October 2011

[29] Shao, Z., Jiang, J., Wang, X., Li, W., Fang, L., Zheng, G., Self-Powered Electrospun Composite Nanofibre Membrane for Highly Efficient Air Filtration, In: Nanomaterials, 2020, 10, 1706

[30] Zhang, D., Tao, Y., Gao, J., Zhang, C., et. al., Pycnogenol® in Cigarette Filters Scavenges Free Radicals and Reduces Mutagenicity and Toxicity of Tobacco Smoke in Vivo., In: Toxicol. and Industrial Health, 2002, 18, 215-224

[31] Hoffmann, D., Hoffmann, I., The Changing Cigarette: 1950-1995, In: J. Toxicol. Environ. Health, 1997, 50, 307-364

[32] Şeker, F.A., Determination of Some Polycyclic Aromatic Hydrocarbons in Filter Tar of Turkish Cigarettes, In: J. Sep. Sci., 2005, 28, 2370-2373

[33] Tian, B.Z., Chen, P., Chen, J., Bai, L., Blocking and Filtering Effect of Bombyx Mori Silkworm Silk Fibre Filter Tips Against Mainstream Smoke of Cigarettes, In: Materials and Design, 2009, 30, 2289-2294

[34] Koller, K.B., Wrenn, S.E., Houck, W.G., Paine, J.B., Cigarette Filter, US Patent No 6,595,218 B1, 2003

[35] King, B., Is the "CGC" Cigarette Filter Additive a Solution for China's Tobacco-induced Disease Problem?, In: Toxicological \& Environmental Chemistry, 2012, 94, 3-6

[36] Pauly, J.L., Rees, V., O'Connor, R., Philip Morris Clinical Study of Carbon Filtered Cigarettes Challenged by Nondisclosure Issues, In: Nicotine \& Tobacco Research, 2009, 11, 1245-1246

[37] Collazo, H., Crow, W.A., Gardner, L., Phillips, B.L., Dyer, W.M., Aerodynamic Diameter Measuremet of Cellulose Acetate Fibres from Cigarette Filters, In: Inhalation Toxicology, 2002, 14, 247-262

[38] Dönmez, S., Production of Nanofibrous Webs for Air Filters By Electrospinning Process, MSc Thesis, Tekirdağ Namık Kemal University, Natural \& Applied Science Institution, Turkey, 2016

[39] Patanaik, A., Anandjiwala, R.D., Rengasamy, R.S., Ghosh, A., Nanotechnology in Fibrous Materials, In: Textile Progress, 2007, 39, 2, 67-120

[40] Andrady, A.L., Science and Technology of Polymer Nanofibres, Jonh Wiley\&Sons, USA, 2008

[41] Zhang, X., Chase, G.G., Solid Aerosol Filtration by Electrospun Pyrrolidene Fibre Mats and Dependence on Pore Size, In: J. Textile Eng. Fashion Techno., 2017, 1, 5, 180-187

[42] Matulevicius, J., Kliucininkas, L., Martuzevicius, D., Krugly, E., Tichonovas, M., Baltrusaitis, J., Design and Characterization of Electrospun Polyamide Nanofibre Media for Air Filtration Applications, In: Journal of Nanomaterials, 2014, Article ID 859656

\section{Authors: \\ SEZEN DÖNMEZ DINÇ ${ }^{1}$, FATMA GÖKTEPE ${ }^{2}$ \\ ${ }^{1}$ Denge Kimya ve Tekstil San. Tic. A. Ş., Tekirdağ, Turkey \\ e-mail:sdinc@denadyes.com, szndnmz@gmail.com \\ ${ }^{2}$ Tekirdağ Namık Kemal University, Department of Textile Engineering, 59860 Çorlu-Tekirdağ, Turkey}

\section{Corresponding author:}

Prof. Dr. FATMA GÖKTEPE

e-mail: fgoktepe@nku.edu.tr, goktepef@gmail.com 